\title{
Stimulation of Insulin Secretion by Amino Acids*
}

\author{
John C. Floyd, Jr., †tefan S. Fajans, Jerome W. Conn, Ralph F. Knopf, \\ AND JUAN Rull \\ (From the Department of Internal Medicine, Division of Endocrinology and Metabolism and \\ the Metabolism Research Unit, the University of Michigan, Ann Arbor, Mich.)
}

In previous studies we have demonstrated that in healthy subjects the ingestion of protein meals results in large increases in plasma levels of insulin and have concluded that this is an important physiologic phenomenon $(1,3)$. In those experiments the magnitude of the increases in plasma insulin exceeded that expected from the small increases in plasma leucine measured (3). In addition, chlorpropamide pretreatment failed to accentuate the protein-induced changes in blood glucose and plasma free fatty acids (3), although it greatly augments such leucine-induced changes $(4,5)$. These findings suggested that amino acids other than leucine or amino acids in combination with leucine stimulate the release of insulin $(1,3$, 6).

The studies described below were performed to assess in healthy subjects the effects upon plasma levels of insulin of the administration of single amino acids and combinations of amino acids with and without leucine. Essential ${ }^{1} l$-amino acids were administered intravenously individually or as mixtures. Plasma levels of insulin, amino nitrogen, free fatty acids, and blood levels of glu-

* Submitted for publication February 24, 1966 ; accepted June 9, 1966.

Supported in part by U. S. Public Health Service grants AM-02244, AM-00888, and TI-AM-5001, National Institute of Arthritis and Metabolic Diseases; 5M01-FR-42-05, Division of Research Facilities and Resources; and U. S. Public Health Service Career Research Award 5-K6-AM-14,237.

Presented in part before the Thirty-seventh Annual Meeting of the Central Society for Clinical Research, Chicago, Ill., November 6 and 7, 1964 (1), and at the National Meeting of the American Federation for Clinical Rèsearch, Atlantic City, N. J., May 2, 1965 (2).

$\dagger$ Address requests for reprints to Dr. John C. Floyd, Jr., University Hospital, University of Michigan Medical Center, Ann Arbor, Mich. 48104.

1 The amino acids employed in this study are indispensable in the diet of animals. Arginine and histidine are not dietary indispensables for the maintenance of nitrogen balance in adult men (7). cose were measured. The results of these studies show $(1,2)$ that 1$)$ the intravenous administration of mixtures of essential amino acids induces the release of insulin, 2) the phenomenon of amino acid-induced release of insulin does not depend upon the presence of leucine in the infusion mixture, and 3) the intravenous administration of individual essential amino acids also induces the release of insulin. However, there are large differences among essential amino acids in their capacity to stimulate the secretion of insulin.

\section{Methods}

Thirty-five healthy males and 3 healthy females between the ages of 19 and 27 years served as subjects for this study. The objectives of the study, the nature of the test materials, and their expected effect upon the test subject were explained to each participant. Fully informed consent for the performance of the tests was thus given by all subjects. Each subject continued his usual diet but took no food for at least 8 hours before testing. A subject was tested with as many of the test materials as possible, and, when feasible, repetitive testing with the same amino acid solutions was performed. Individual amino acids and mixtures of 2 to 10 amino acids were administered intravenously in amounts of from 2.5 to $30 \mathrm{~g}$. The composition of the mixture of $10 \mathrm{es}-$ sential amino acids and of mixtures of 6 to 8 amino acids (solutions A through $\mathrm{G}$ ), administered in $30-\mathrm{g}$ amounts, is given in Table I. Other mixtures were made up of $2,3,4,5$, or 8 amino acids in the same amounts in which they had been present in the $30 \mathrm{~g}$ of the mixture of 10 amino acids.

During or after the infusion of some individual amino acids a few subjects experienced untoward reactions, the details of which are given in the Results. When reactions occurred, further testing at or beyond that dose level was not performed and is not recommended.

Essential $l$-amino acids ${ }^{2}$ were obtained in crystalline form as the pure amino acids except for lysine, which was the hydrochloride. In some instances histidine and arginine also were obtained as the hydrochloride. Aqueous amino acid solutions were prepared in concentrations

2 Amino acids were purchased from Nutritional Biochemicals Corp., Cleveland, Ohio, and the General Biochemical Co., Chagrin Falls, Ohio. 
TABLE I

Compositions of solutions containing $30 \mathrm{~g}$ of amino acids

\begin{tabular}{|c|c|c|c|c|c|c|c|c|c|c|}
\hline Amino acid & & & $10 \mathrm{AA}$ & A & в & $\mathrm{c}$ & $\mathrm{D}$ & $\mathrm{E}$ & $\mathrm{F}$ & G \\
\hline & $\begin{array}{c}\text { mmoles/ } \\
30 \mathrm{~g}\end{array}$ & & & & & & & & & \\
\hline Arginine & 172 & $\underset{\mathrm{mmoles}}{\mathrm{g}}$ & $\begin{array}{c}2.91 \\
16.7\end{array}$ & $\begin{array}{c}3.89 \\
22.4\end{array}$ & $\begin{array}{c}3.86 \\
22.2\end{array}$ & $\begin{array}{c}4.06 \\
23.3\end{array}$ & $\begin{array}{c}4.31 \\
24.8\end{array}$ & $\begin{array}{c}5.20 \\
29.9\end{array}$ & $\begin{array}{c}5.14 \\
29.5\end{array}$ & \\
\hline Lysine & 205 & $\underset{\text { mmoles }}{\mathrm{g}}$ & $\begin{array}{c}4.53 \\
31.0\end{array}$ & $\begin{array}{c}6.05 \\
41.4\end{array}$ & & $\begin{array}{c}6.32 \\
43.3\end{array}$ & $\begin{array}{c}6.71 \\
46.0\end{array}$ & $\begin{array}{c}8.09 \\
55.4\end{array}$ & & \\
\hline Phenylalanine & 183 & $\underset{\mathrm{mmoles}}{\mathrm{g}}$ & $\begin{array}{l}3.90 \\
23.6\end{array}$ & $\begin{array}{c}5.21 \\
31.6\end{array}$ & $\begin{array}{c}5.17 \\
31.3\end{array}$ & . & $\begin{array}{c}5.78 \\
35.0\end{array}$ & & & $\begin{array}{c}5.17 \\
31.3\end{array}$ \\
\hline Leucine & 229 & $\underset{\mathrm{m} m o l e s}{\mathrm{~g}}$ & $\begin{array}{c}4.71 \\
36.0\end{array}$ & & $\begin{array}{c}6.25 \\
47.7\end{array}$ & $\begin{array}{c}6.57 \\
50.2\end{array}$ & & & $\begin{array}{l}8.32 \\
63.5\end{array}$ & $\begin{array}{c}\quad 6.25 \\
47.7\end{array}$ \\
\hline Methionine & 201 & $\underset{\mathrm{m}}{\mathrm{g}}$ & $\begin{array}{c}2.85 \\
19.1\end{array}$ & $\begin{array}{c}3.81 \\
25.6\end{array}$ & & $\begin{array}{l}3.97 \\
26.6\end{array}$ & $\begin{array}{l}4.22 \\
28.3\end{array}$ & $\begin{array}{l}5.09 \\
34.2\end{array}$ & $\begin{array}{c}5.04 \\
33.8\end{array}$ & $\begin{array}{c}3.86 \\
25.9\end{array}$ \\
\hline Valine & 256 & $\underset{\mathrm{mmoles}}{\mathrm{g}}$ & $\begin{array}{l}3.60 \\
30.8\end{array}$ & $\begin{array}{c}4.81 \\
41.1\end{array}$ & $\begin{array}{c}4.77 \\
40.8\end{array}$ & & $\begin{array}{c}5.33 \\
45.6\end{array}$ & & & $\begin{array}{c}4.77 \\
40.8\end{array}$ \\
\hline Histidine & 194 & $\underset{\mathrm{mmoles}}{\mathrm{g}}$ & $\begin{array}{l}1.47 \\
9.5\end{array}$ & $\begin{array}{c}1.95 \\
12.6\end{array}$ & $\begin{array}{c}1.95 \\
12.6\end{array}$ & $\begin{array}{c}2.05 \\
13.2\end{array}$ & $\begin{array}{c}2.18 \\
14.1\end{array}$ & $\begin{array}{c}2.62 \\
16.9\end{array}$ & $\begin{array}{c}2.60 \\
16.8\end{array}$ & $\begin{array}{c}1.95 \\
12.6\end{array}$ \\
\hline Isoleucine & 229 & $\underset{\mathrm{mmoles}}{\mathrm{g}}$ & $\begin{array}{c}2.82 \\
21.5\end{array}$ & & $\begin{array}{c}3.74 \\
28.5\end{array}$ & $\begin{array}{c}3.93 \\
30.0\end{array}$ & & $\begin{array}{c}5.04 \\
38.5\end{array}$ & $\begin{array}{c}4.98 \\
38.0\end{array}$ & $\begin{array}{l}3.75 \\
28.5\end{array}$ \\
\hline Threonine & 252 & $\stackrel{\mathrm{g}}{\mathrm{mmoles}}$ & $\begin{array}{c}2.22 \\
18.7\end{array}$ & $\begin{array}{c}2.96 \\
24.9\end{array}$ & $\begin{array}{c}2.94 \\
24.7\end{array}$ & $\begin{array}{c}3.10 \\
26.1\end{array}$ & & $\begin{array}{l}3.96 \\
33.3\end{array}$ & $\begin{array}{c}3.92 \\
33.0\end{array}$ & $\begin{array}{c}2.94 \\
24.7\end{array}$ \\
\hline Tryptophan & 147 & $\underset{\mathrm{m} m o l e s}{\mathrm{~g}}$ & $\begin{array}{l}0.99 \\
4.9\end{array}$ & $\begin{array}{l}1.32 \\
6.5\end{array}$ & $\begin{array}{l}1.31 \\
6.4\end{array}$ & & $\begin{array}{l}1.47 \\
7.2\end{array}$ & & & $\begin{array}{l}1.31 \\
6.4\end{array}$ \\
\hline $\begin{array}{l}\text { Total amount of } \\
\text { amino acids per } \\
\text { mixture }\end{array}$ & & $\underset{\mathrm{mmoles}}{\mathrm{g}}$ & $\begin{array}{c}30.0 \\
211.8\end{array}$ & $\begin{array}{r}30.0 \\
206.1\end{array}$ & $\begin{array}{r}30.0 \\
214.2\end{array}$ & $\begin{array}{r}30.0 \\
212.7\end{array}$ & $\begin{array}{r}30.0 \\
201.0\end{array}$ & $\begin{array}{r}30.0 \\
208.2\end{array}$ & $\begin{array}{r}30.0 \\
214.6\end{array}$ & $\begin{array}{r}30.0 \\
217.9\end{array}$ \\
\hline
\end{tabular}

of 1 to $10 \mathrm{~g}$ per $100 \mathrm{ml}$, depending upon the solubilities of the amino acids in water. Sodium chloride was added to all solutions of less than $5 \mathrm{~g}$ of amino acid per $100 \mathrm{ml}$ to bring the osmolality to about $300 \mathrm{mOsm}$ per $\mathrm{kg}$ water. Sodium carbonate or hydrochloric acid was added as appropriate to bring the final $\mathrm{pH}$ of the solutions to 7.4. The volume of a solution to be administered depended upon the concentration and the amount of amino acid to be infused. Thirty $\mathrm{g}$ of individual amino acids was dissolved in from $300 \mathrm{ml}$ (arginine, lysine) to 1,500 $\mathrm{ml}$ (leucine, phenylalanine). Solutions were passed through a Millipore filter, placed in dispensing bottles, and autoclaved. Solutions containing tryptophan were not autoclaved, since this procedure discolors such solutions. After bottling, representative bottles were tested for the presence of bacterial or pyrogenic contamination.

After a 30-minute period of control measurements, solutions were administered intravenously over the succeeding 30 minutes. Venous blood was sampled during the control period $(-30,-15,-1,0$ minutes as shown in Tables), every 10 minutes during the first hour after the beginning of the infusion, every 15 minutes during the second hour, and every 30 minutes during the third hour. On some occasions, either 1 hour before, at 2 to $2 \frac{1}{2}$ hours after the beginning of an infusion of amino acids, or at both times, glucose $(2.5$ to $10 \mathrm{~g})$ as a $50 \%$ solution or glucagon $(6.25$ to $50 \mu \mathrm{g})$ was administered by rapid iv injection, and blood samples were obtained at intervals of from 5 to 10 minutes for an additional 30 minutes. Four subjects received an iv infusion of $30 \mathrm{~g}$ of glucose administered as a $10 \%$ solution over 30 minutes.

Concentrations of blood glucose were determined with the Technicon autoanalyzer with frequent verification by the Somogyi-Nelson technique (8). Levels of plasma insulin were determined by the immunoassay method of Yalow and Berson (9). The details of the assay as performed in this laboratory have been given in earlier publications $(5,10)$. Increases in plasma insulin were expressed as maximal increases above control levels (average of the -1 - and 0 -minute values) and also as the sum of increments in plasma insulin over control levels during the first hour of the test. Plasma levels of amino nitrogen were determined by the method of Frame, Russell, and Wilhelmi (11). Results of measurements made during and after the administration of lysine are corrected to account for the fact that both amino groups of lysine appear to react quantitatively with the naptho- 
quinone color reagent (11). Plasma free fatty acid was measured by the method of Dole (12).

\section{Results}

\section{1) Ten essential amino acids}

Thirty $\mathrm{g}$ of a mixture of 10 essential amino acids (10 AA) was administered intravenously 51 times to 35 subjects.

Plasma insulin. Plasma insulin was measured in 48 tests and rose in each (Table II). Maximal increases ranged from 37 to 301 (mean 120) $\mu \mathrm{U}$ per $\mathrm{ml}$ and occurred at 10 to 30 (mean 26) minutes. Mean plasma insulin rose from a control level of $9 \mu \mathrm{U}$ per $\mathrm{ml}$ and reached a peak of 120 $\mu \mathrm{U}$ per $\mathrm{ml}$ at 30 minutes. It declined almost to basal levels $(17 \mu \mathrm{U}$ per $\mathrm{ml}$ ) at 60 minutes and to $13 \mu \mathrm{U}$ at 120 minutes (Table II and Figure 1).

Plasma amino nitrogen. Plasma amino nitrogen was measured in 13 tests and rose in each (Table II). Maximal increases ranged from 6.1 to 10.5 (mean 8.6) $\mathrm{mg}$ per $100 \mathrm{ml}$ and occurred at 20 to 30 (mean 28) minutes. Mean plasma amino nitrogen rose from a control level of $4.6 \mathrm{mg}$ per 100 $\mathrm{ml}$, reached a peak of $13.1 \mathrm{mg}$ per $100 \mathrm{ml}$ at 30 minutes, declined rapidly to $8.2 \mathrm{mg}$ per $100 \mathrm{ml}$ at 60 minutes, and to 5.6 and $5.2 \mathrm{mg}$ per $100 \mathrm{ml}$ at 120 and 180 minutes, respectively (Table II, Figure 1).

Blood glucose. Blood glucose was measured in all 51 tests (Table II). It increased $5 \mathrm{mg}$ per $100 \mathrm{ml}$ or more from control levels in 48 tests and decreased $5 \mathrm{mg}$ per $100 \mathrm{ml}$ or more from control levels in 39 tests. Maximal increases ranged from 0 to 36 (mean 14) $\mathrm{mg}$ per $100 \mathrm{ml}$ and occurred at 10 to 30 (mean 16) minutes (Table II). Maximal decreases from control levels ranged from 0 to 41 (mean 15 ) $\mathrm{mg}$ per $100 \mathrm{ml}$ and occurred at 40 to 180 (mean 54) minutes. Mean blood glucose rose from a control level of $85 \mathrm{mg}$ per $100 \mathrm{ml}$ to a peak of $97 \mathrm{mg}$ per $100 \mathrm{ml}$ at 10 and 20 minutes. It fell to $72 \mathrm{mg}$ per $100 \mathrm{ml}$ at 50 minutes and returned to control levels at 90 minutes (Table II, Figure 1).

Plasma free fatty acid. Plasma FFA was measured in 16 tests and decreased more than $100 \mu \mathrm{Eq}$ per L in 13 (Table II). Maximal decreases ranged from 33 to 641 (mean 262) $\mu \mathrm{Eq}$ per $\mathrm{L}$ and occurred at 10 to 150 (mean 68) minutes. Mean concentration fell from a control value of 577 to $391 \mu \mathrm{F}$.q per L at 90 minutes (Table II, Figure 1).

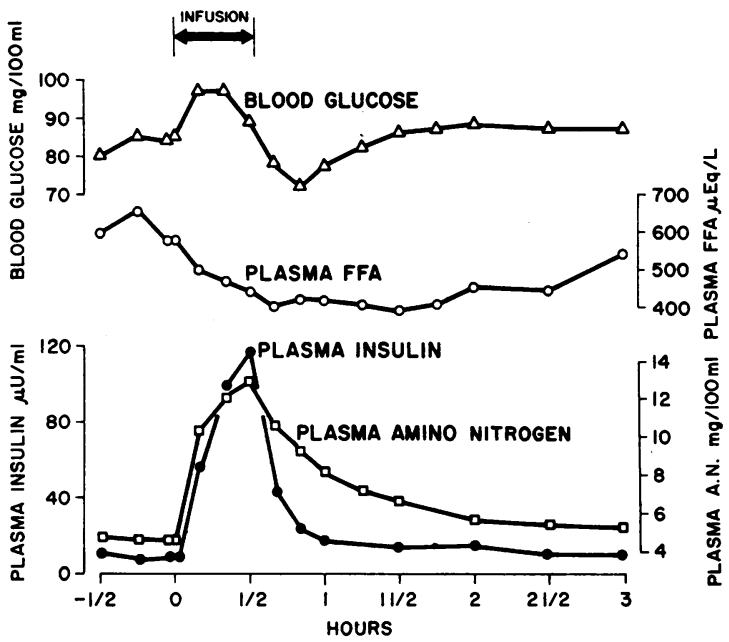

Fig. 1. EFfect of IV administration of 30 g of A MIXTURE OF 10 ESSENTIAL AMINO ACIDS UPON MEAN PLASMA INSULIN, AMINo NITROGEN, FREE FATTY ACIDS, AND BLOOD GLUCOSE IN 35 heALThy SUBJECTS TESTED 51 TIMES.

\section{2) Leucine $4.71 \mathrm{~g}$ and isoleucine $2.82 \mathrm{~g}$}

The amount of leucine plus isoleucine contained in the $30-\mathrm{g}$ mixture of $10 \mathrm{AA}$ was administered intravenously to 6 subjects; the results are shown in Table III. Plasma insulin was measured during 4 of these tests. Maximal increases ranged from 4 to 15 (mean 9) $\mu \mathrm{U}$ per $\mathrm{ml}$ and occurred at 10 to 30 (mean 20) minutes. The increases, when expressed as the sum of increments during the first hour, were one-tenth of those obtained with the 10 AA mixture administered to the same subjects. Maximal increases in blood glucose for the 6 tests ranged from 1 to 8 (mean 3 ) $\mathrm{mg}$ per $100 \mathrm{ml}$ and occurred at from 10 to 180 (mean 70) minutes. Maximal decreases in blood glucose ranged from 7 to 15 (mean 10) $\mathrm{mg}$ per $100 \mathrm{ml}$ and occurred at 40 to 75 (mean 52) minutes.

\section{3) Eight essential amino acids}

Leucine and isoleucine were excluded from the $30 \mathrm{~g}$ mixture of 10 essential amino acids. This reduced the number of amino acids in the infusion mixture to 8 and the amount of amino acids infused to $22.5 \mathrm{~g}$. As a control for this reduction lysine and methionine were excluded from the $30-\mathrm{g}$ mixture of 10 amino acids. This reduced the amount of amino acid administered in this infusion to $22.6 \mathrm{~g}$. These two mixtures 
TABLE II

Levels of plasma insulin and amino nitrogen, blood glucose, and plasma free fatty

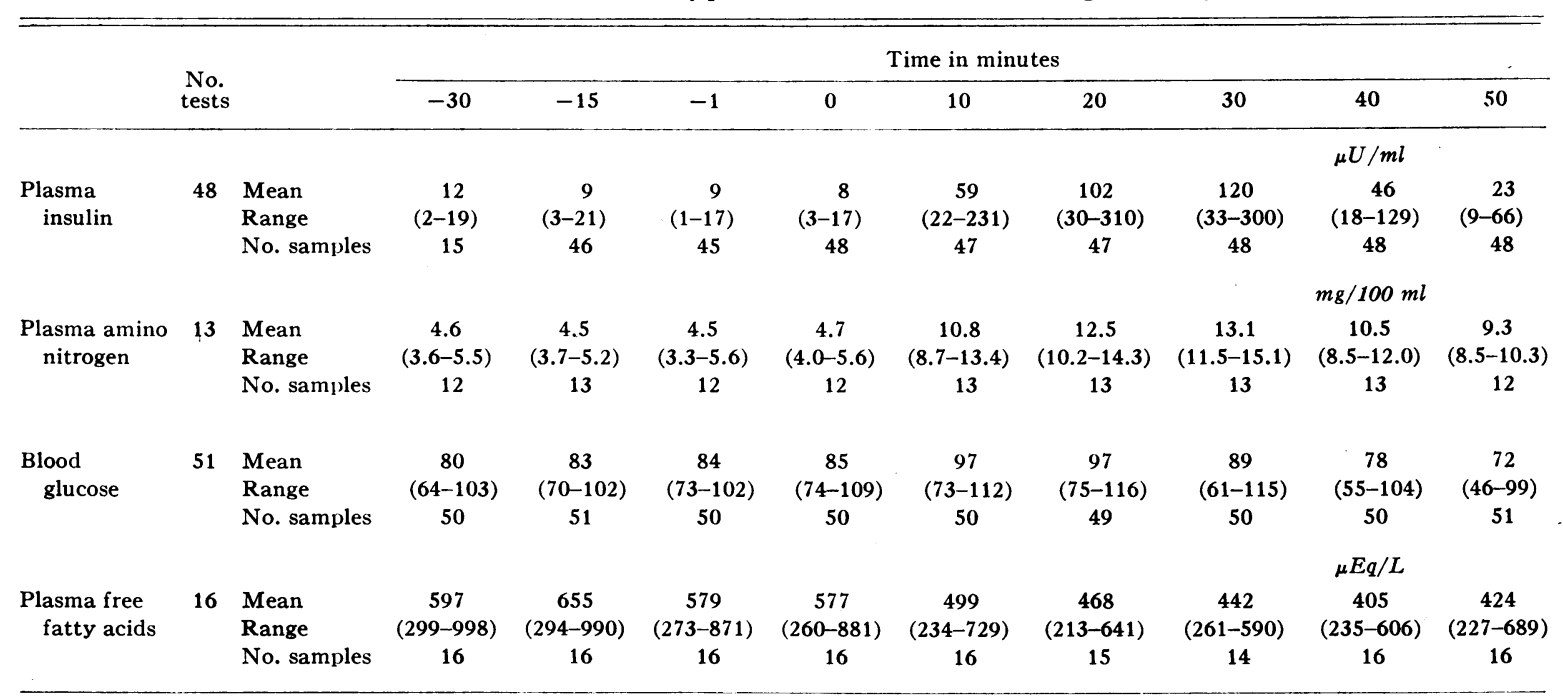

were administered to 11 and 6 subjects, respectively. A summary of their effects upon plasma insulin, amino nitrogen, and blood glucose is given in Table III. When the number and amount of amino acids infused were reduced, the 1-hour insulin increment decreased in each subject. In addition, it is evident that the mixture which did not contain leucine produced almost the same mean of maximal increases and mean sum of increments in plasma insulin as did. the mixture which contained leucine. Both mixtures produced much greater increases than did the amount of leucine plus isoleucine (infused separately) contained in the 10 AA mixture.

The upper part of Table IV compares the mean sums of increments in plasma insulin in subjects who received either both the 30 -g 10 amino acid mixture $(346 \mu \mathrm{U}$ per $\mathrm{ml})$ and the 22.5 -g solution lacking leucine and isoleucine $(187 \mu \mathrm{U}$ per $\mathrm{ml})$ or the $30-\mathrm{g}$ mixture of $10 \mathrm{AA}(353 \mu \mathrm{U}$ per $\mathrm{ml})$ and the 22.6-g solution lacking lysine and methionine (180 $\mu \mathrm{U}$ per $\mathrm{ml}$ ). In both circumstances the mean sums of increments in plasma insulin for the 30-g 10 amino acid solution were significantly greater than for the solutions containing 22.5 and $22.6 \mathrm{~g}$ amino acids.

\section{4) Thirty-g amounts of individual amino acids}

Arginine, lysine, phenylalanine, leucine, valine, methionine, and histidine were administered indi- vidually in $30-\mathrm{g}$ amounts. $^{3}$ Arginine (172 mmoles) and valine (256 mmoles) varied by more than $15 \%$ from the millimoles of amino acids administered in the 10 AA mixture (212 mmoles) (Table I). Details concerning the number of test subjects, the number of tests, and the effects of these solutions upon the magnitude and time of changes in plasma insulin, amino nitrogen, and blood glucose are shown in Table V.

The mean of maximal increases in plasma insulin ranged from $81 \mu \mathrm{U}$ per $\mathrm{ml}$ for arginine to $3 \mu \mathrm{U}$ per $\mathrm{ml}$ for histidine. The mean of maximal increases in plasma amino nitrogen was $10.3 \mathrm{mg}$ per

\footnotetext{
3 Because both subjects when given methionine experienced untoward effects, only two infusions of this amino acid were given. One subject developed nausea and vomiting after completion of the test period. The other subject experienced a severe reaction that began soon after the infusion was completed. This was characterized in the first few hours by nausea, vomiting, increased sweating, chill followed by fever, moderate hypotension, tachycardia, and intermittent disorientation. At 18 hours there was mild azotemia and biochemical evidence of moderately severe hepatic dysfunction. Therapy consisted of intravenous glucose and electrolyte solutions and oral fluids. The blood pressure remained at levels of 80 to 90 systolic and 50 to 60 diastolic for about 36 hours, after which it began to return toward normal and the subject was no longer febrile. After 4 days the subject was virtually asymptomatic, and at 9 days liver function tests were normal. They were normal on repeat testing 1 and $3 \stackrel{1}{2}$ months later.
} 
TABLE II

acids after the iv administration of a 30-g mixture of 10 essential amino acids

\begin{tabular}{|c|c|c|c|c|c|c|c|c|c|c|}
\hline \multicolumn{7}{|c|}{ Time in minutes } & \multirow{2}{*}{$\begin{array}{l}\text { Maximal } \\
\text { increase }\end{array}$} & \multirow{2}{*}{$\begin{array}{l}\text { Time of } \\
\text { maximal } \\
\text { increase }\end{array}$} & \multirow{2}{*}{$\begin{array}{l}\text { Maximal } \\
\text { decrease }\end{array}$} & \multirow{2}{*}{$\begin{array}{c}\text { Time of } \\
\text { maximal } \\
\text { decrease }\end{array}$} \\
\hline 60 & 75 & 90 & 105 & 120 & 150 & 180 & & & & \\
\hline & & & & & & & $\mu U / m l$ & minutes & & \\
\hline 17 & 16 & 14 & 13 & 13 & 11 & 9 & 120 & 26 & & \\
\hline$(2-45)$ & $(11-23)$ & $(1-23)$ & $(5-18)$ & $(5-19)$ & $(5-16)$ & $(5-13)$ & $(37-301)$ & $(10-30)$ & & \\
\hline \multirow[t]{2}{*}{48} & 10 & 47 & 10 & 11 & 10 & 10 & & & & \\
\hline & & & & & & & $m g / 100 m l$ & & & \\
\hline 8.2 & 7.1 & 6.6 & 5.9 & 5.6 & 5.3 & 5.2 & 8.6 & 28 & & \\
\hline$(6.0-9.0)$ & $(5.4-7.9)$ & $(5.8-7.4)$ & $(4.5-6.5)$ & $(5.0-6.2)$ & $(4.4-6.0)$ & $(4.2-5.7)$ & $(6.1-10.5)$ & $(20-30)$ & & \\
\hline \multirow[t]{2}{*}{13} & 13 & 13 & 12 & 11 & 12 & 7 & & & & \\
\hline & & & & & & & & & $\mathrm{mg} / 100 \mathrm{ml}$ & minutes \\
\hline $\begin{array}{c}77 \\
(45-95)\end{array}$ & $\begin{array}{c}82 \\
(60-97)\end{array}$ & $\begin{array}{c}86 \\
(73-104)\end{array}$ & $\begin{array}{c}87 \\
(76-104)\end{array}$ & $\begin{array}{c}88 \\
(79-103)\end{array}$ & $\begin{array}{c}87 \\
(78-100)\end{array}$ & $\begin{array}{c}87 \\
(75-99)\end{array}$ & $\begin{array}{c}14 \\
(0-36)\end{array}$ & $\begin{array}{c}16 \\
(10-30)\end{array}$ & $\begin{array}{c}15 \\
(0-41)\end{array}$ & $\begin{array}{c}54 \\
(40-180)\end{array}$ \\
\hline \multirow[t]{2}{*}{50} & 51 & 51 & 51 & 51 & 49 & 48 & & & & \\
\hline & & & & & & & & & $\mu E q / L$ & \\
\hline 419 & 407 & 391 & 407 & 454 & 442 & 544 & & & 262 & 68 \\
\hline$(253-661)$ & $(259-656)$ & $(196-577)$ & $(178-686)$ & $(250-861)$ & (273-948) & $(307-993)$ & 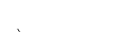 & & $(33-641)$ & $(10-150)$ \\
\hline 16 & 15 & 16 & 16 & 16 & 15 & 15 & & & & \\
\hline
\end{tabular}

$100 \mathrm{ml}$ for arginine and $9.6 \mathrm{mg}$ per $100 \mathrm{ml}$ for histidine.

Table VI gives the mean sums of increments in plasma insulin for subjects who received both the $30-\mathrm{g} 10$ AA solution and one or more of the various amino acids administered individually in $30-\mathrm{g}$ amounts. Infusion of $30 \mathrm{~g}$ of arginine (172 mmoles) caused a mean sum of increments in plasma insulin of $257 \mu \mathrm{U}$ per ml, whereas $30 \mathrm{~g}$ of the 10 AA mixture ( 212 mmoles) caused a mean sum of increments of $299 \mu \mathrm{U}$ per ml. An analysis of paired differences showed these results not to be significantly different. This analysis was also applied to the following sets of observations: $10 \mathrm{AA}$

TABLE III

Changes in plasma insulin, amino nitrogen, and blood glucose after iv administration of essential amino acids

\begin{tabular}{|c|c|c|c|c|c|c|c|c|c|c|c|}
\hline \multirow[b]{2}{*}{ Amino acid solution } & \multirow[b]{2}{*}{$\begin{array}{l}\text { No. } \\
\text { tests }\end{array}$} & \multirow[b]{2}{*}{$\begin{array}{l}\text { No. } \\
\text { subjects }\end{array}$} & \multirow[b]{2}{*}{$\begin{array}{l}\text { Amount } \\
\text { infused }\end{array}$} & \multicolumn{3}{|c|}{ Plasma insulin } & \multicolumn{2}{|c|}{$\begin{array}{c}\text { Plasma amino } \\
\text { nitrogen }\end{array}$} & \multicolumn{3}{|c|}{ Blood glucose } \\
\hline & & & & $\begin{array}{l}\text { Maximal } \\
\text { increase* }\end{array}$ & & $\begin{array}{l}\text { ments during } \\
\text { first hour* }\end{array}$ & $\underset{\text { increase* }}{\text { Maximal }}$ & & $\begin{array}{l}\text { Maxima } \\
\text { increase }\end{array}$ & & $\begin{array}{l}\text { Maximal } \\
\text { decrease* }\end{array}$ \\
\hline 10 AA & 51 & 35 & $\begin{array}{c}g \\
30.0\end{array}$ & $\begin{array}{c}\mu U / m l \\
120 \\
(37-301)\end{array}$ & 47 & $\begin{array}{c}\mu U / m l \\
312 \\
(102-822)\end{array}$ & $\begin{array}{c}m g / 100^{\circ} \mathrm{ml} \\
8.6 \\
(6.1-10.5)\end{array}$ & 13 & $\begin{array}{c}m g / 100 n \\
14 \\
(0-36)\end{array}$ & $\begin{array}{l}m l \\
50\end{array}$ & $\begin{array}{c}m g / 100 m l \\
15 \\
(0-41)\end{array}$ \\
\hline $\begin{array}{l}\text { Leucine } 4.71 \mathrm{~g}+ \\
\text { isoleucine } 2.82 \mathrm{~g}\end{array}$ & 6 & 6 & 7.53 & $\stackrel{9}{(4-15)}$ & 4 & $\begin{array}{c}32 \\
(14-47)\end{array}$ & & & $\stackrel{3}{(1-8)}$ & 6 & $\begin{array}{c}10 \\
(7-15)\end{array}$ \\
\hline $\begin{array}{l}\text { 10 AA minus leucine and } \\
\text { isoleucine }\end{array}$ & 11 & 11 & 22.5 & $\begin{array}{c}73 \\
(23-213)\end{array}$ & 10 & $\begin{array}{c}187 \\
(56-534)\end{array}$ & & & $\stackrel{15}{(2-35)}$ & 11 & $\begin{array}{c}10 \\
(0-31)\end{array}$ \\
\hline 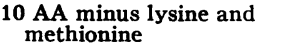 & 6 & 6 & 22.6 & $\begin{array}{c}61 \\
(34-97)\end{array}$ & 6 & $\begin{array}{c}180 \\
(85-262)\end{array}$ & & & $\begin{array}{c}11 \\
(7-23)\end{array}$ & 6 & $\begin{array}{c}9 \\
(2-16)\end{array}$ \\
\hline A & 10 & 10 & 30.0 & $\begin{array}{c}73 \\
(46-127)\end{array}$ & & $\begin{array}{c}213 \\
(121-341)\end{array}$ & $\begin{array}{c}10.0 \\
(8.9-11.7)\end{array}$ & 7 & $\begin{array}{c}18 \\
(13-29)\end{array}$ & 10 & $\begin{array}{c}12 \\
(0-25)\end{array}$ \\
\hline B & 11 & 11 & 30.0 & $\begin{array}{c}77 \\
(13-209)\end{array}$ & & $\begin{array}{c}187 \\
(50-459)\end{array}$ & $(6.8-10.6)$ & 9 & $\stackrel{13}{(7-22)}$ & 11 & $\begin{array}{c}7 \\
(0-24)\end{array}$ \\
\hline C & 7 & 7 & 30.0 & $\begin{array}{c}80 \\
(29-140)\end{array}$ & 7 & $\begin{array}{c}233 \\
(86-409)\end{array}$ & $\begin{array}{l}10.5 \\
(7.8-12.5)\end{array}$ & 7 & $\begin{array}{c}17 \\
(11-27)\end{array}$ & 7 & $\begin{array}{c}18 \\
(6-30)\end{array}$ \\
\hline D & 6 & 6 & 30.0 & $\begin{array}{c}101 \\
(50-227)\end{array}$ & 6 & $\begin{array}{c}287 \\
(130-599)\end{array}$ & $(8.8-10.3)$ & 6 & $\begin{array}{c}29 \\
(18-42)\end{array}$ & 6 & $\begin{array}{c}10 \\
(0-23)\end{array}$ \\
\hline E & 7 & 7 & 30.0 & $\begin{array}{c}92 \\
(32-287)\end{array}$ & 7 & $\begin{array}{l}239 \\
(85-708)\end{array}$ & $(9.4-12.6)$ & 7 & $\stackrel{22}{(8-37)}$ & 7 & $\begin{array}{c}14 \\
(2-47)\end{array}$ \\
\hline $\mathbf{F}$ & 7 & 7 & 30.0 & $\begin{array}{c}58 \\
(13-81)\end{array}$ & 7 & $\begin{array}{c}152 \\
(30-252)\end{array}$ & $(6.6-9.4)$ & 7 & $\stackrel{9}{(5-15)}$ & 7 & $\begin{array}{c}8 \\
(0-20)\end{array}$ \\
\hline G & 4 & 4 & 30.0 & ${ }^{37}(28-49)$ & 4 & $\begin{array}{c}142 \\
(112-179)\end{array}$ & & & $\stackrel{4}{4}$ & 4 & $(3-21)$ \\
\hline
\end{tabular}

* Mean and range. The number of tests on which analysis was performed is given to the right of the figures for the range. 
TABLE IV

Comparison in the same subjects of the increments in plasma insulin after the iv administration of the 10 amino acid mixture and mixtures of 6 to 8 amino acids

\begin{tabular}{|c|c|c|c|c|}
\hline Amino acid solution & $\underset{\text { infused }}{\text { Amount }}$ & $\begin{array}{l}\text { No. subjects } \\
\text { and tests }\end{array}$ & $\begin{array}{l}\text { Mean sum of incre- } \\
\text { ments in plasma insulin } \\
\text { during first hour }\end{array}$ & Analysis of paired differences \\
\hline $10 \mathrm{AA}$ & $30^{g}$ & 10 & $\begin{array}{c}\mu U / m l \\
346 \\
(165-791)\end{array}$ & \multirow{2}{*}{$0.001<\mathrm{p}<0.01$} \\
\hline $\begin{array}{l}\text { 10 AA minus leucine and } \\
\text { isoleucine }\end{array}$ & 22.5 & 10 & $\begin{array}{c}187 \\
(56-534)\end{array}$ & \\
\hline $10 \mathrm{AA}$ & 30 & 6 & $\begin{array}{c}353 \\
(172-791)\end{array}$ & \multirow{2}{*}{$0.01<\mathrm{p}<0.05$} \\
\hline $\begin{array}{l}10 \text { AA minus lysine and } \\
\text { methionine }\end{array}$ & 22.6 & 6 & $\begin{array}{c}180 \\
(85-262)\end{array}$ & \\
\hline $10 \mathrm{AA}$ & 30 & 10 & $\begin{array}{c}291 \\
(133-791)\end{array}$ & \multirow{2}{*}{ NS } \\
\hline A & 30 & 10 & $\begin{array}{c}213 \\
(121-341)\end{array}$ & \\
\hline $10 \mathrm{AA}$ & 30 & 11 & $\begin{array}{c}288 \\
(133-791)\end{array}$ & \multirow{2}{*}{$0.001<\mathrm{p}<0.01$} \\
\hline B & 30 & 11 & $\begin{array}{c}187 \\
(50-459)\end{array}$ & \\
\hline $10 \mathrm{AA}$ & 30 & 7 & $\begin{array}{c}297 \\
(156-791)\end{array}$ & \multirow{2}{*}{ NS } \\
\hline $\mathrm{C}$ & 30 & 7 & $\begin{array}{c}233 \\
(86-409)\end{array}$ & \\
\hline $10 \mathrm{AA}$ & 30 & 6 & $\begin{array}{c}315 \\
(134-791)\end{array}$ & \multirow{2}{*}{ NS } \\
\hline $\mathrm{D}$ & 30 & 6 & $\begin{array}{c}287 \\
(130-599)\end{array}$ & \\
\hline $10 \mathrm{AA}$ & 30 & 7 & $\begin{array}{c}322 \\
(134-791)\end{array}$ & \multirow{2}{*}{$p=0.02$} \\
\hline $\mathrm{E}$ & 30 & 7 & $\begin{array}{c}239 \\
(85-708)\end{array}$ & \\
\hline $10 \mathrm{AA}$ & 30 & 7 & $\begin{array}{c}279 \\
(134-791)\end{array}$ & \multirow{2}{*}{$0.05<\mathrm{p}<0.1$} \\
\hline $\mathrm{F}$ & 30 & 7 & $\begin{array}{c}153 \\
(30-252)\end{array}$ & \\
\hline $10 \mathrm{AA}$ & 30 & 4 & $\begin{array}{c}301 \\
(179-415)\end{array}$ & \multirow{2}{*}{$0.02<\mathrm{p}<0.05$} \\
\hline G & 30 & 4 & $\begin{array}{c}149 \\
(112-179)\end{array}$ & \\
\hline
\end{tabular}

10 AA vs. A, B, p $<0.05$; D vs. A, B, p $<0.05 ; 10$ AA, D, each vs. F, p $<0.02 *$

* Results from seven subjects given $10 \mathrm{AA}, \mathrm{A}, \mathrm{B}, \mathrm{C}, \mathrm{D}, \mathrm{E}$, and F were subjected to factorial analysis of variance by the techniques of Rao for analysis of dispersion for multiple classified data with unequal numbers of cells. Comparisons with significant differences are shown.

vs. lysine, $10 \mathrm{AA}$ vs. leucine, $10 \mathrm{AA}$ vs. phenyl- acid solution (Table VI). Eight subjects received alanine, $10 \mathrm{AA}$ vs. valine, and $10 \mathrm{AA}$ vs. histidine. the $10 \mathrm{AA}$ solution, arginine, lysine, and leucine In each case the sum of increments in plasma insu- (one subject did not receive lysine, another leulin was significantly greater for the $30-\mathrm{g} 10$ amino cine). A factorial analysis of variance showed 
TABLE V

Changes in plasma insulin, amino nitrogen, and blood glucose after iv administration of essential amino acids

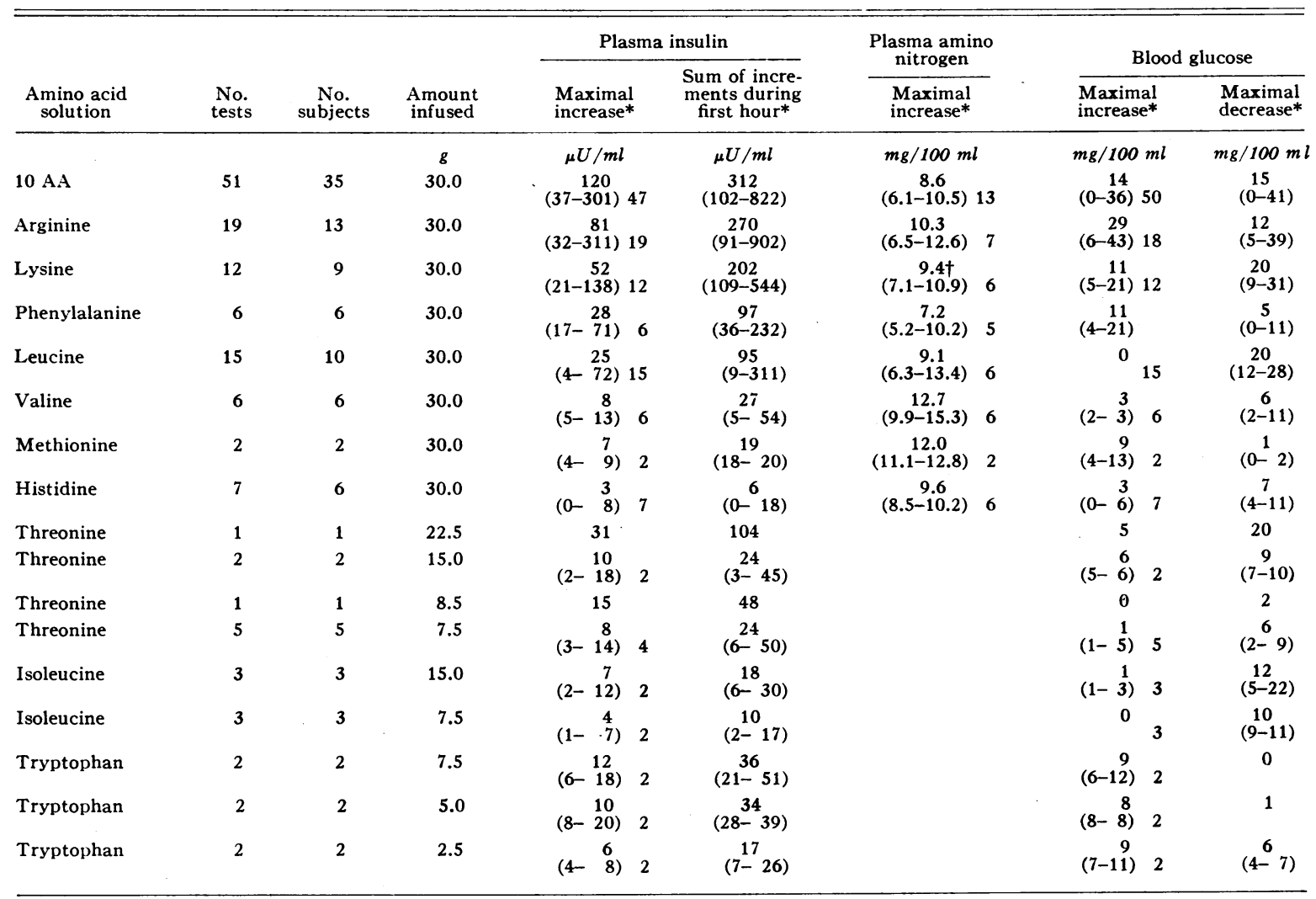

* Mean and range. The number of tests on which analysis was performed is given to the right of the figures for the range.

$\dagger$ Values of amino nitrogen corrected; see Methods.

that there were significant differences among the increases in plasma insulin induced by these solutions $[\mathrm{F}$ (variance ratio) $=9.39 ; \mathrm{df}$ (degrees of freedom $)=3,19 ; \mathrm{p}<0.001]$. The $10 \mathrm{AA}$ solution and arginine were equipotent; $10 \mathrm{AA}$ but not arginine was more potent than lysine; $10 \mathrm{AA}$, arginine, and lysine were each more potent than leucine (Table VI). The 7 amino acids are listed as follows according to decreasing magnitude of the insulin responses obtained: arginine, lysine, leucine, phenylalanine, valine, methionine, and histidine.

Threonine, isoleucine, and tryptophan were not administered individually in $30-\mathrm{g}$ amounts, ${ }^{4}$ but

4 Three subjects received infusions of $15 \mathrm{~g}$ of isoleucine. About 30 minutes after the completion of the infusion one subject had mild backache followed at $45 \mathrm{~min}$ utes by a chill and subsequent fever. After several hours blood pressure declined to 98 systolic, 30 to 20 diastolic. After 16 hours the patient became afebrile, and blood when given individually in amounts from 2.5 to $22.5 \mathrm{~g}$ did result in increases in plasma levels of insulin (Table V).

pressure became normal. There were no abnormal laboratory findings except for a leukocyte count of 13,200 . There were no sequellae.

Six subjects received infusions of threonine. One subject experienced headache $3 \frac{1}{2}$ hours after receiving an infusion of $7.5 \mathrm{~g}$ of threonine. Another subject experienced transient back pain during the infusion, which was discontinued at 10 minutes when $8.5 \mathrm{~g}$ had been given. A third subject experienced severe headache and chill followed by mild elevation of body temperature. These symptoms began about 30 to 45 minutes after he had received an infusion of $22.5 \mathrm{~g}$ of threonine and abated about 2 hours after they had begun.

Three subjects received 6 infusions of tryptophan. One subject experienced transient facial flushing, nausea, and brachycardia beginning 20 minutes after he had received an infusion of $7.5 \mathrm{~g}$ of tryptophan. This, plus the similar experience of another investigator (13), indicated that this dosage of tryptophan probably should not be exceeded. 
TABLE VI

Comparison in the same subjects of the increments in plasma insulin after the iv administration of the 10 amino acid mixture and individual amino acids

\begin{tabular}{|c|c|c|c|c|}
\hline$\underset{\text { solution }}{\text { Amino acid }}$ & $\underset{\text { infused }}{\text { Amount }}$ & $\begin{array}{l}\text { No. sub- } \\
\text { jects and } \\
\text { tests }\end{array}$ & $\begin{array}{l}\text { Mean sum of in- } \\
\text { crements in plasma } \\
\text { insulin during } \\
\text { first hour }\end{array}$ & Analysis of paired differences \\
\hline $10 \mathrm{AA}$ & $\begin{array}{c}g \\
30\end{array}$ & 11 & $\begin{array}{c}\mu U / m l \\
299 \\
(123-822)\end{array}$ & \multirow{2}{*}{ NS } \\
\hline Arginine & 30 & 11 & $\begin{array}{c}257 \\
(109-572)\end{array}$ & \\
\hline $10 \mathrm{AA}$ & 30 & 9 & $\begin{array}{c}329 \\
(133-822)\end{array}$ & \multirow{2}{*}{$0.01<\mathrm{p}<0.05$} \\
\hline Lysine & 30 & 9 & $\begin{array}{c}209 \\
(109-544)\end{array}$ & \\
\hline $10 \mathrm{AA}$ & 30 & 10 & $\begin{array}{c}308 \\
(201-670)\end{array}$ & \multirow[b]{2}{*}{$0.001<p<0.01$} \\
\hline Leucine & 30 & 10 & $\begin{array}{c}105 \\
(29-311)\end{array}$ & \\
\hline $10 \mathrm{AA}$ & 30 & 5 & $\begin{array}{c}312 \\
(213-517)\end{array}$ & \multirow{4}{*}{$0.001<\mathrm{p}<0.01$} \\
\hline Phenylalanine & 30 & 5 & $\begin{array}{c}99 \\
(36-232)\end{array}$ & \\
\hline $10 \mathrm{AA}$ & 30 & 2 & $\begin{array}{c}173 \\
(133-213)\end{array}$ & \\
\hline Methionine & 30 & 2 & $\begin{array}{c}19 \\
(18-20)\end{array}$ & \\
\hline $10 \mathrm{AA}$ & 30 & 6 & $\begin{array}{c}326 \\
(133-822)\end{array}$ & \multirow{2}{*}{$0.01<\mathrm{p}<0.05$} \\
\hline Valine & 30 & 6 & $\stackrel{27}{(5-54)}$ & \\
\hline $10 \mathrm{AA}$ & 30 & 6 & $\begin{array}{c}397 \\
(249-822)\end{array}$ & \multirow{2}{*}{$0.01<\mathrm{p}<0.05$} \\
\hline Histidine & 30 & 6 & $(0-18)$ & \\
\hline
\end{tabular}

* Results from eight subjects given $10 \mathrm{AA}$, arginine, lysine, and leucine were subjected to factorial analysis of variance by the techniques of Rao for analysis of dispersion for multiple classified data with unequal numbers of cells. Comparisons with significant differences are shown.

\section{5) Thirty-g mixtures of 6 to 8 essential amino acids}

The amino acid compositions of the mixtures designated solutions $A$ through $G$ are given in Table I. The number of millimoles of amino acids administered corresponded very closely to that contained in the $10 \mathrm{AA}$ mixture. Details concerning the number of test subjects, the number of tests performed, and the effects of these infusions upon the magnitude of changes in plasma insulin, amino nitrogen, and blood glucose are shown in Table III. Table IV shows the mean sum of increments in plasma insulin in those subjects who received both the $30-\mathrm{g} 10$ amino acid mixture and the $30 \mathrm{~g}$ mixtures of 6 to 8 amino acids. The mean sum of increments was smallest for solutions $B, F$, and $G$ when compared to that obtained with the $10 \mathrm{AA}$ solution given to the same subjects. Among the amino acids excluded from solutions $B, F$, and $G$ were arginine or lysine 
TABLE VII

Effect in the same subjects of repeated administration of amino acid solutions upon sum of increments in plasma insulin during first hour after start of infusion

\begin{tabular}{|c|c|c|c|c|c|c|c|c|c|c|}
\hline \multirow{2}{*}{$\begin{array}{l}\text { Subject } \\
\text { W.V. }\end{array}$} & \multicolumn{2}{|c|}{$\begin{array}{c}10 \text { amino acids* } \\
\text { Sum of increments (SI) } \\
\text { in plasma insulin } \\
\text { during first hour }\end{array}$} & \multicolumn{2}{|c|}{$\underset{\text { SI }}{\text { Arginine* }}$} & \multicolumn{2}{|c|}{$\begin{array}{c}\text { Lysine } \\
\text { SI }\end{array}$} & \multicolumn{2}{|c|}{$\begin{array}{c}\text { Leucine } \\
\text { SI }\end{array}$} & \multicolumn{2}{|c|}{$\begin{array}{l}\text { Histidine } \\
\text { SI }\end{array}$} \\
\hline & $\begin{array}{l}2 / 18 / 64 \\
8 / 13 / 64\end{array}$ & $\begin{array}{l}\mu U / m l \\
240 \\
102\end{array}$ & & $\mu U / m l$ & & $\mu U / m \boldsymbol{l}$ & 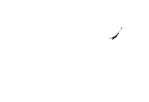 & $\mu U / m l$ & & $\mu U / m l$ \\
\hline D.Hi. & $\begin{array}{l}2 / 07 / 64 \\
9 / 16 / 64\end{array}$ & $\begin{array}{l}311 \\
201\end{array}$ & & & & & & & & \\
\hline D.S. & $\begin{array}{r}9 / 10 / 64 \\
10 / 14 / 64\end{array}$ & $\begin{array}{l}134 \\
213\end{array}$ & & & & & $\begin{array}{r}9 / 23 / 64 \\
10 / 28 / 64\end{array}$ & $\begin{array}{r}9 \\
29\end{array}$ & & \\
\hline J.A. & $\begin{array}{r}2 / 07 / 64 \\
9 / 10 / 64 \\
10 / 14 / 64\end{array}$ & $\begin{array}{l}338 \\
293 \\
213\end{array}$ & $\begin{array}{r}9 / 29 / 64 \\
10 / 03 / 64\end{array}$ & $\begin{array}{l}173 \\
366\end{array}$ & $\begin{array}{r}9 / 15 / 64 \\
11 / 24 / 64\end{array}$ & $\begin{array}{l}143 \\
158\end{array}$ & $\begin{array}{r}4 / 10 / 64 \\
9 / 22 / 64 \\
10 / 27 / 64\end{array}$ & $\begin{array}{r}149 \\
79 \\
98\end{array}$ & & \\
\hline G.M. & $\begin{array}{r}9 / 25 / 64 \\
10 / 30 / 64 \\
11 / 05 / 64\end{array}$ & $\begin{array}{l}517 \\
752 \\
822\end{array}$ & $\begin{array}{l}10 / 02 / 64 \\
12 / 04 / 64\end{array}$ & $\begin{array}{l}902 \\
572\end{array}$ & & & & & $\begin{array}{l}11 / 12 / 64 \\
11 / 25 / 64\end{array}$ & $\begin{array}{r}5 \\
18\end{array}$ \\
\hline R.D. & $\begin{array}{r}9 / 29 / 64 \\
10 / 20 / 64\end{array}$ & $\begin{array}{l}337 \\
252\end{array}$ & $\begin{array}{l}10 / 13 / 64 \\
11 / 10 / 64\end{array}$ & $\begin{array}{l}279 \\
188\end{array}$ & & & $\begin{array}{l}10 / 06 / 64 \\
10 / 27 / 64\end{array}$ & $\begin{array}{r}72 \\
131\end{array}$ & & \\
\hline J.F. & $\begin{array}{l}1 / 34 / 64 \\
1 / 24 / 64\end{array}$ & $\begin{array}{l}328 \\
783\end{array}$ & & & & & & & & \\
\hline D.H. & $\begin{array}{r}2 / 18 / 64 \\
10 / 08 / 64 \\
12 / 10 / 64\end{array}$ & $\begin{array}{l}165 \\
294 \\
242\end{array}$ & $\begin{array}{l}10 / 01 / 64 \\
11 / 24 / 64\end{array}$ & $\begin{array}{l}274 \\
204\end{array}$ & $\begin{array}{r}9 / 17 / 64 \\
11 / 19 / 64\end{array}$ & $\begin{array}{l}222 \\
258\end{array}$ & $\begin{array}{l}10 / 29 / 64 \\
11 / 05 / 64\end{array}$ & $\begin{array}{l}67 \\
77\end{array}$ & & \\
\hline D.L. & $\begin{array}{l}2 / 22 / 64 \\
4 / 15 / 64\end{array}$ & $\begin{array}{l}172 \\
256\end{array}$ & & & $\begin{array}{l}11 / 20 / 64 \\
12 / 04 / 64\end{array}$ & $\begin{array}{l}183 \\
147\end{array}$ & & & & \\
\hline M.S. & $\begin{array}{l}10 / 16 / 64 \\
10 / 30 / 64\end{array}$ & $\begin{array}{l}401 \\
423\end{array}$ & $\begin{array}{l}10 / 09 / 64 \\
10 / 23 / 64\end{array}$ & $\begin{array}{l}160 \\
199\end{array}$ & & & & & & \\
\hline R.M. & $\begin{array}{l}2 / 06 / 64 \\
4 / 28 / 64\end{array}$ & $\begin{array}{l}119 \\
499\end{array}$ & & & & & & & & \\
\hline L.B. & & & $\begin{array}{r}6 / 30 / 65 \\
10 / 07 / 65\end{array}$ & $\begin{array}{l}212 \\
194\end{array}$ & & & & & & \\
\hline
\end{tabular}

* For 10 amino acids and for arginine, interindividual variability in response was greater than intraindividual variability $(\mathrm{p}<0.05$, see text).

or both, each of which ranked high in its ability to cause increases in plasma insulin when given individually.

The increments in plasma insulin obtained with the $10 \mathrm{AA}$ solution and with solutions A through $G$ were subjected to an analysis of paired differences. The increments in plasma insulin obtained with solutions $B, E$, and $G$ were significantly less than those for the 10 AA solution. The increments obtained with solution $F$ were less in each subject than those with 10 amino acids; however, the difference in the mean sums of increments was at the borderline of significance. Seven subjects received solutions $10 \mathrm{AA}, \mathrm{A}, \mathrm{B}, \mathrm{C}, \mathrm{D}, \mathrm{E}$, and $\mathrm{F}$ (one did not receive $\mathrm{D}$ and one $\mathrm{E}$ ). The results, which differed significantly from each other, are shown in Table IV. Increases in plasma insulin were smallest for solution $F$ (Table IV).

Table III shows that of solutions A through $F$ only the infusion of solution $\mathrm{F}$ resulted in a mean of maximal increases in plasma amino nitrogen which was slightly less than that obtained during the infusion of the 10 AA solution.

6) Repetitive administration of amino acid solutions to the same individuals

The results shown in Tables II, III, IV, V, and VI indicate that there was considerable vari- 


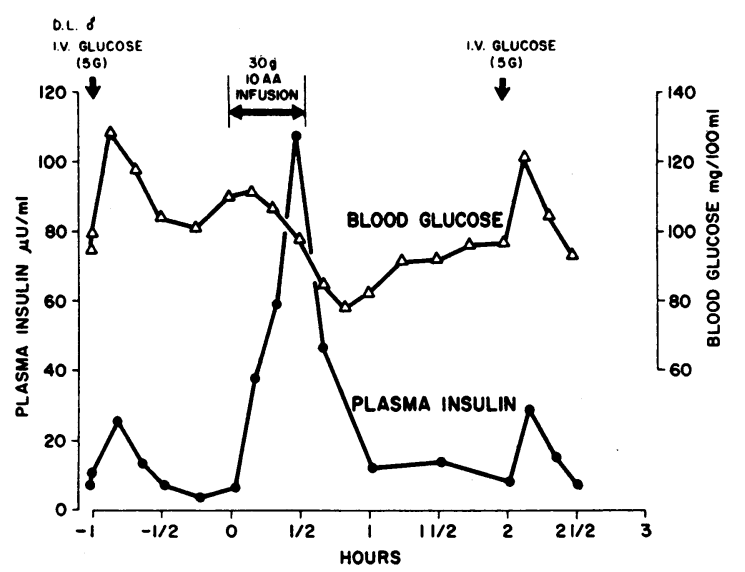

Fig. 2. EFFEct of IV administration of $5.0 \mathrm{G}$ GLUCOSE, BEFORE AND AFTER THE IV ADMINISTRATION OF $30.0 \mathrm{G}$ OF A MIXTURE OF 10 ESSENTIAL AMINo ACIDS, UPON BLOOD GLUCOSE AND PLASMA INSULIN IN A HEALTHY SUBJECT.

ability among subjects in their plasma insulin response to infusions of any one of the amino acid solutions. To ascertain the intraindividual variability in changes in plasma insulin when the same solution is administered repetitively, we administered several of the amino acid solutions to the same subjects on two or three occasions at intervals of 4 days to 10 months. These results are expressed as the sum of increments in plasma insulin during the first hour (Table VII). Some subjects were reasonably consistent in their responses to a given solution, but considerable variability is evident in others. In subject G.M. values in the high range were found consistently for either the 10 AA solution $(517,752,822 \mu \mathrm{U}$ per $\mathrm{ml})$ or arginine $(902,572 \mu \mathrm{U}$ per $\mathrm{ml})$. Nevertheless, considerable variability is evident within this high range. In subject D.H. increments in plasma insulin were in a more intermediate range and were more reproducible for a given solution-10 AA : 165, 294, $242 \mu \mathrm{U}$ per $\mathrm{ml}$; arginine : 274,204 $\mu \mathrm{U}$ per $\mathrm{ml}$; lysine : $222,258 \mu \mathrm{U}$ per $\mathrm{ml}$; and leucine: 67 and $77 \mu \mathrm{U}$ per ml. Between the test giving $165 \mu \mathrm{U}$ per $\mathrm{ml}$ with the 10 amino acid solution and the two tests resulting in increases of 294 and $242 \mu \mathrm{U}$ per $\mathrm{ml}$ there were intervals of 8 and 10 months, respectively.

A two factor analysis of variance was employed for the results obtained with the 10 amino acid solution and with arginine. This analysis showed that the variation in the magnitude of the re- sponses among individuals was greater than the variation within individuals, i.e., a response of a given individual differed more on the average from the response of another person than it did from his own second response (10 AA : $F=3.61$, $\mathrm{df}=10,14, \mathrm{p}<0.05 ;$ arginine $: \mathrm{F}=6.65, \mathrm{df}=$ $5,6, \mathrm{p}<0.05)$.

\section{7) Intravenous administration of glucose and glu- cagon}

Glucose or glucagon was administered by rapid iv injection in an effort to produce increases in blood levels of glucose of a magnitude similar to those observed during the infusion of amino acids. Comparisons were made in the same subjects of levels of plasma insulin and blood glucose during the infusion of amino acid solutions with levels found after the administration of 2.5 to $10.0 \mathrm{~g}$ of glucose (6 tests in 5 subjects) or of 6.25 to $50.0 \mu \mathrm{g}$ of glucagon (11 tests in 7 subjects). The amino acid solutions employed for these tests were 1) 10.4 - to $17.8 \mathrm{-g}$ mixtures of 3,4 , or 5 amino acids each present in the amount in which it was present in the $10 \mathrm{AA}$ solution, and 2) $30 \mathrm{-g}$ amounts of lysine, 10 AA solution, and solutions $\mathrm{E}$ and $\mathrm{F}$.

The mean of maximal increases in blood glucose was significantly greater after the administration of glucose (22 mg per $100 \mathrm{ml}$ ) than during the amino acid infusion ( $6 \mathrm{mg}$ per $100 \mathrm{ml})(\mathrm{p}=$ $0.025)$. The mean of maximal increases in plasma insulin was greater during the infusion of amino acids (34 $\mu \mathrm{U}$ per $\mathrm{ml}$ ) than during the infusion of glucose $(10 \mu \mathrm{U}$ per $\mathrm{ml}) \quad(0.05<\mathrm{p}<0.10)$. When glucagon was administered, the mean of maximal increases in blood glucose $(20 \mathrm{mg}$ per $100 \mathrm{ml}$ ) was similar to that obtained during infusion of amino acids (15 mg per $100 \mathrm{ml}$ ) ( $p>$ $0.40)$. In addition, the mean sum of increments in blood glucose above control levels after glucagon administration was similar to that obtained with amino acid administration. However, the mean of maximal increases in plasma insulin was significantly greater after administration of amino acids (90 $\mu \mathrm{U}$ per $\mathrm{ml}$ ) than after that of glucagon (13 $\mu \mathrm{U}$ per $\mathrm{ml})(0.01<\mathrm{p}<0.025)$. Figure 2 shows that a large increase in plasma insulin $(102 \mu \mathrm{U}$ per $\mathrm{ml}$ ) occurred during an infusion of the $30 \mathrm{~g}$ of 10 AA solution in subject D.L. without an in- 
TABLE VIII

Comparison in the same subjects of the effect upon plasma insulin and blood glucose of the iv administration of $30 \mathrm{~g}$ of the 10 amino acid mixture and of $30 \mathrm{~g}$ of glucose*

\begin{tabular}{|c|c|c|c|c|c|c|c|c|c|}
\hline & & \multicolumn{4}{|c|}{ Plasma insulin } & \multicolumn{4}{|c|}{ Blood glucose } \\
\hline \multirow[b]{2}{*}{ Subject } & & \multicolumn{2}{|c|}{$\begin{array}{l}\text { Maximal } \\
\text { increases }\end{array}$} & \multicolumn{2}{|c|}{$\begin{array}{l}\text { Sum of increments } \\
\text { during first hour }\end{array}$} & \multicolumn{2}{|c|}{$\begin{array}{l}\text { Maximal } \\
\text { increases }\end{array}$} & \multicolumn{2}{|c|}{$\begin{array}{l}\text { Sum of increments } \\
\text { during first hour }\end{array}$} \\
\hline & & $10 \mathrm{AA}$ & $\overline{\text { Glucose }}$ & $10 \mathrm{AA}$ & $\overline{\text { Glucose }}$ & $10 \mathrm{AA}$ & $\overline{\text { Glucose }}$ & $10 \mathrm{AA}$ & Glucose \\
\hline & & \multicolumn{4}{|c|}{$\mu U / m l$} & \multicolumn{4}{|c|}{$\mathrm{mg} / 100 \mathrm{ml}$} \\
\hline $\begin{array}{l}\text { G.M. } \\
\text { G.M. } \\
\text { T.T. } \\
\text { M.S. } \\
\text { J.W. }\end{array}$ & & $\begin{array}{r}259 \\
265 \\
42 \\
150 \\
197\end{array}$ & $\begin{array}{l}93 \\
67 \\
35 \\
25 \\
39\end{array}$ & $\begin{array}{l}752 \\
822 \\
123 \\
423 \\
533\end{array}$ & $\begin{array}{l}400 \\
315 \\
167 \\
122 \\
189\end{array}$ & $\begin{array}{r}17 \\
12 \\
6 \\
36 \\
17\end{array}$ & $\begin{array}{l}149 \\
143 \\
172 \\
160 \\
138\end{array}$ & $\begin{array}{r}46 \\
23 \\
6 \\
112 \\
41\end{array}$ & $\begin{array}{l}567 \\
594 \\
651 \\
749 \\
639\end{array}$ \\
\hline & Mean & 183 & 52 & 531 & 239 & 18 & 152 & 46 & 640 \\
\hline
\end{tabular}

* Solutions were administered over a period of 30 minutes. Composition of the 10 amino acid solution is given in Table I. Glucose was administered as a $10 \%$ solution in water.

crease in blood glucose. Five $\mathrm{g}$ of glucose, given intravenously to this subject 1 hour before and 2 hours after the administration of the $30 \mathrm{~g}$ of the 10 amino acid solution, produced maximal increases in blood glucose of 31 and $25 \mathrm{mg}$ per 100 $\mathrm{ml}$. These increases in blood glucose were accompanied by maximal increases in plasma insulin of only 16 and $21 \mu \mathrm{U}$ per ml, respectively.

On 5 occasions 4 subjects were given $30 \mathrm{~g}$ of glucose intravenously as a $10 \%$ solution over a period of 30 minutes. Table VIII compares the levels of plasma insulin and blood glucose that resulted from the glucose infusion with those that resulted from the infusion of the same number of grams of amino acids. The mean of maximal increases and the mean sum of increments in blood glucose were significantly greater during the infusion of glucose than during the infusions of the amino acids $(p<0.001)$. In contrast, the mean of maximal increases and mean sum of increments in plasma insulin were greater during the infusion of amino acids than during the infusion of glucose.

\section{Discussion}

The intravenous administration of a $30 \mathrm{~g}$ mixture of 10 essential amino acids to healthy subjects induces prompt and large increases in levels of plasma insulin. The mean of maximal increases in plasma insulin was $120 \mu \mathrm{U}$ per $\mathrm{ml}$, and the mean sum of increments in plasma insulin during the first hour was $312 \mu \mathrm{U}$ per ml. These acute changes in plasma insulin can be interpreted to reflect increases in the secretory rate of insulin, since the fractional rate of degradation of the hormone is independent of hormonal concentration over wide limits $(14,15)$. In addition, by simultaneous measurement of plasma insulin in portal and peripheral blood, we have shown that the intravenous administration of the mixture of $10 \mathrm{AA}$ induces the release of insulin from the pancreatic beta cells (16). By the same technique we had demonstrated previously that leucine evokes release of pancreatic insulin (17). However, the magnitude of the increases in plasma insulin after administration of the 10 amino acid mixture suggested that amino acids, other than leucine, also play an important role as stimuli of insulin secretion. The results of earlier studies had shown that an amount of leucine much larger than that contained in the $10 \mathrm{AA}$ mixture caused smaller increases in plasma insulin than those obtained with the 10 AA mixture (5). Furthermore, when the amount of leucine and isoleucine contained in the $10 \mathrm{AA}$ mixture was administered as such, the mean sum of increments in plasma insulin was only $32 \mu \mathrm{U}$ per $\mathrm{ml}$ (Table III). Thus, the stimulation of insulin secretion by the $10 \mathrm{AA}$ mixture was not induced solely by the leucine contained therein.

Further studies showed $a$ ) that the ability of the 10 AA mixture to stimulate the secretion of large amounts of insulin was not due to the potentiation by other amino acids of leucine-induced insulin release, and $b$ ) that the phenomenon of amino acid-induced release of insulin does not depend on the presence of leucine in the infusion 
mixture. When leucine and isoleucine were excluded from the mixture of $10 \mathrm{AA}$, the results were almost the same as when lysine and methionine were excluded, the mean sums of increments in plasma insulin being 187 and $180 \mu \mathrm{U}$ per ml, respectively (Tables III and IV). When each of the 10 amino acids contained in the 10 AA mixture was administered individually, it was found that all except histidine stimulated the release of insulin (Tables V, VI). Arginine was the most effective and valine the least effective of the active amino acids.

At a level of $30 \mathrm{~g}$, arginine and the 10 AA mixture resulted in mean sums of increments in plasma insulin that were not significantly different ( $\mathrm{Ta}$ ble VI), even though on a molar basis the amount of arginine was $19 \%$ less than that of the $10 \mathrm{AA}$ mixture. The mean sums of increments were significantly greater, however, for the 10 amino acid mixture than for lysine, leucine, phenylalanine, valine, and histidine. When comparisons were made in 8 subjects who each received 10 AA, arginine, lysine, and leucine, the mean sum of increments in plasma insulin induced by $30-\mathrm{g}$ amounts of the $10 \mathrm{AA}$ solution was significantly greater than that induced by $30 \mathrm{~g}$ of lysine. The increments obtained with the $10 \mathrm{AA}$ solution, arginine, and lysine were each significantly greater than those obtained with leucine (Table VI). Since threonine, isoleucine, and tryptophan were not administered in 30-g amounts, no direct comparison of potency with those of the 7 other amino acids is possible. Even in reduced amounts, however, they appear to be at least as potent as $30 \mathrm{~g}$ of valine and methionine. The potency of threonine and tryptophan would appear to approach that of leucine and phenylalanine in causing the release of insulin (Table V). Thus, these data indicate that individual essential amino acids in addition to leucine stimulate the release of insulin, that there are large differences among them in this capacity, and that several of the individual amino acids are more potent than leucine in this regard. The magnitudes of maximal increases in plasma amino nitrogen reached during the infusion of the various amino acids were similar, whereas the magnitude of increases in plasma insulin varied greatly.

When one attempts to determine the contribution made by individual amino acids to the total secretion of insulin induced by the mixture of 10 amino acids (Tables I, III, and IV), conclusions become more tentative, although some seem justified. Solutions B, F, and $G$ gave the smallest mean sums of increments in plasma insulin ( $\mathrm{Ta}$ bles III and IV). Amino acids excluded from these solutions were arginine or lysine or both, amino acids that ranked high in the capacity to induce release of insulin when given individually. The mean of maximal increases in plasma insulin was smallest with solution $G$, the only solution to contain neither arginine nor lysine. Plasma levels of amino nitrogen were similar during the infusions of the 10 AA mixture and of each of solutions A through F (Table III). Thus, the smaller increments of plasma insulin measured when solutions $B$ and $F$ were infused were not the result of smaller increases in levels of total plasma amino acids during their infusion.

A comparison of the effectiveness of various amino acids and mixtures of amino acids in evoking the release of insulin must be made with caution. As is evident from Table VII, there is, among individual subjects, a wide range in magnitude of increases in levels of plasma insulin upon administration of a particular amino acid solution. However, when a particular amino acid solution was administered, the variation in the response between individuals was significantly greater than that within a given individual. Therefore, statistical comparisons among the responses evoked by different solutions have been made only when the responses were measured in the same subjects.

It is likely that the infused amino acids themselves provide the stimulus that induces the increased rate of secretion of insulin, although direct evidence is available only for leucine. We have demonstrated previously that leucine itself, rather than one of its metabolites, induces the release of insulin after its administration $(10,18)$. In the data of the present studies there is shown to exist a close temporal relationship between the rises and falls of plasma amino acids and plasma insulin for those amino acids that stimulate insulin secretion (Figure 1).

An explanation for the differences among the various amino acids in their abilities to elicit the release of insulin is not apparent. No obvious common physicochemical property or configuration 
characterizes the more potent or less potent amino acids. The dibasic amino acids, arginine and lysine, appeared to be the more potent of the amino acids tested. Yet, histidine, also a dibasic amino acid, was the least potent. Duplicate determinations of the $\mathrm{pH}$ of venous blood of 3 subjects were made on samples obtained during the control periods and at the 30-minute point when the infusions of arginine were completed. The respective mean $\mathrm{pH}$ values for the two sampling times were 7.41 and 7.40 .

Those individual amino acids and mixtures of amino acids infusion of which was accompanied by the largest and most consistent increases in blood glucose (10 AA, arginine, lysine, solutions A through $\mathrm{E}$ ) were the most potent in stimulating release of insulin. The studies with infusions of glucose or glucagon made it clear, however, that the blood glucose elevations observed with the amino acid infusions could not account solely for the phenomenon. The rapid injection of glucose produced increases in blood glucose significantly greater than those observed during amino acid infusions, but the resulting increases in plasma insulin were smaller during the glucose infusions. The increases in blood glucose after administration of glucagon or amino acids were similar in magnitude, whereas the increases in plasma insulin were significantly larger during infusions of amino acids. This was so in spite of the fact that glucagon can enhance the secretion of insulin by other means in addition to its ability to increase blood glucose $(19,20)$. The intravenous administration of 30 $\mathrm{g}$ of glucose over a period of 30 minutes produced blood levels of glucose that were much higher and more prolonged than those observed during the administration of the same amount of $10 \mathrm{AA}$ to the same subject. Yet, the maximal increases and sum of increments in plasma insulin were much greater during the infusion of amino acids than during the infusion of glucose. Thus, the large increases in plasma insulin observed during the infusions of amino acids cannot be the result of the small increases in blood glucose. In addition, amino acid-induced elevations of blood glucose are not necessary accompaniments of increased insulin secretion induced by amino acid (see leucine and Figure 2).

The initial increases in blood glucose (range 0 to $43 \mathrm{mg}$ per $100 \mathrm{ml}$ ) observed during the infu- sion of the various amino acid solutions may be due to gluconeogenesis from the infused amino acids. When arginine, a glucogenic amino acid, was administered, the mean of maximal increases in blood glucose was large (29 $\mathrm{mg}$ per $100 \mathrm{ml}$ ). There were no increases in blood glucose with the nonglucogenic amino acid leucine. However, the other 8 individual amino acids produced no major differences in increases in blood sugar, and there was not a good correlation between mean increases in blood glucose and their usual classification as to glucogenicity. Arginine, valine, histidine, and threonine are classified as glucogenic; isoleucine as weakly glucogenic; phenylalanine as questionably glucogenic; and leucine, lysine, methionine, and tryptophan as nonglucogenic ( 7$)$. This classification of amino acids is based upon the metabolic fate of amino acids in experimental animals under conditions of diabetes and starvation (7). The fate of these amino acids when infused into healthy subjects after they have fasted overnight may not be the same.

Cahill (21) has shown the gluconeogenesis from amino acids begins virtually instantaneously upon their perfusion through the liver. In addition, he has shown that the amount of glucose released from the liver is related directly to the quantity of amino acid infused into the liver. Thus, rapid gluconeogenesis is a metabolic event that would provide a plausible explanation for the increases in blood glucose that occur during the infusion of certain amino acids and mixtures of amino acids. However, the presence of accelerated gluconeogenesis may not be the only factor contributing to the observed elevations in blood glucose.

The decreases in blood glucose (range 0 to 47 $\mathrm{mg}$ per $100 \mathrm{ml}$ ) that were observed after the infusion of amino acids are very likely the result of the preceding release of insulin. The mean of maximal decrease in blood glucose occurred 28 minutes after the mean of maximal increases in plasma insulin that resulted from the administration of the 10 AA mixture. This temporal relationship suggests that the hyperinsulinemia plays an important role in the causation of the decreases in blood glucose. Additional support for this interpretation comes from the studies of Mellinkoff, Shibata, Frankland, and Greipel (22). After a $10 \%$ casein hydrolysate solution was administered to a nondiabetic group (normal volunteers and 
nondiabetic patients), these investigators observed an initial increase in blood glucose above control levels followed by a decrease in blood glucose below control levels. When the same solution was administered to patients with total pancreatectomy, the increases in blood glucose were greater and more prolonged, and there were no decreases in blood glucose below control levels during the 4-hour period of observation.

In healthy subjects the increases in plasma insulin that result from the infusion of amino acids would tend to moderate the increases in blood glucose that result from gluconeogenesis. These increases in blood glucose, when they occur, may, in turn, moderate the magnitude of the decreases in blood glucose that result from the hyperinsulinemia. After the infusion of leucine, which produced no increases in blood glucose, mean decreases in blood glucose were relatively large (20 $\mathrm{mg}$ per $100 \mathrm{ml}$ ) although the mean of maximal increases in plasma insulin was modest $(25 \mu \mathrm{U}$ per $\mathrm{ml}$ ). In contrast, after the infusion of arginine, which produced large mean maximal increases in blood glucose (29 $\mathrm{mg}$ per $100 \mathrm{ml}$ ), mean maximal decreases in blood glucose $(12 \mathrm{mg}$ per $100 \mathrm{ml}$ ) were modest in relation to mean of maximal increases in plasma insulin $(81 \mu \mathrm{U}$ per $\mathrm{ml}$ ). Yet, the latter were more than three times as large as after the infusion of leucine.

The effect of the hyperinsulinemia is evidenced not only by the decreases in blood glucose, modest though they are, but also by the decreases in plasma FFA. After the infusion of the $10 \mathrm{AA}$ mixture mean plasma FFA fell from basal levels of $577 \mu \mathrm{Eq}$ per $\mathrm{L}$ to a nadir of $391 \mu \mathrm{Eq}$ per $\mathrm{L}$ at 90 minutes, and maximal decreases were as large as $641 \mu \mathrm{Eq}$ per L. Subsequently, as plasma insulin continued to fall toward basal levels, plasma FFA returned towards control levels. An additional effect of the induced hyperinsulinemia may be evident. Plasma amino nitrogen remained higher after the infusion of valine and histidine than after the infusion of the 10 AA mixture, arginine, lysine, and leucine. Valine evokes only modest elevations in plasma insulin; histidine is virtually without effect in this regard. These results suggest that the more rapid clearance of amino nitrogen from the plasma after the infusions of the 10 AA mixture, arginine, lysine, and leucine is related to the increased amounts of in- sulin released by these amino acids. In line with this interpretation are the results of Mellinkoff and his associates (22) that after intravenously administered casein hydrolysate normal people exhibit a smaller rise of amino nitrogen and a more rapid decline than do patients with a total pancreatectomy.

From the point of view of normal physiology we have shown that the ingestion of a protein meal constitutes a stimulus for the release of insulin (3). The hyperinsulinemia could facilitate intracellular utilization of amino acids in protein synthesis. Ingestion of a protein meal and intravenous administration of arginine, lysine, histidine, phenylalanine, leucine, valine, or methionine induce also a release into the blood of growth hormone $(23,24)$, a finding confirmed with respect to arginine by Merimee, Lillicrap, and Rabinowitz (25). In this parameter, too, there are differences among these amino acids in their abilities to stimulate the release of growth hormone. Maximal plasma levels of growth hormone occur at 1 to 2 hours after the beginning of amino acid infusions. Thus, the endocrine response to protein feeding or to intravenously administered amino acids includes release of both insulin and growth hormone in a timed sequence, the different amino acids varying in their capabilities to evoke either or both of these responses. The established roles in protein biosynthesis of both insulin and "growth" hormone, and their synergistic activities, emphasize the importance of our findings with respect to the daily regulation of amino acid utilization in man.

\section{Summary}

Essential $l$-amino acids, either as mixtures or individually, were administered intravenously to healthy subjects. The various mixtures, whether they contained leucine or not, and most, but not all, of the individual amino acids stimulated the release of insulin. The most effective stimulus for insulin release was either a mixture of 10 essential amino acids or arginine given alone; histidine was the least effective. Administration of the mixture of 10 amino acids on the one hand, and of arginine on the other, caused means of maximal increases in plasma insulin of 120 (range 37 to 301 ) and of 81 (range 32 to 311 ) $\mu \mathrm{U}$ per ml, respec- 
tively. After the infusion of many of the single amino acids and of the amino acid mixtures, blood glucose increased above control levels initially and then decreased below control levels. The increases in blood glucose may be the result of increased gluconeogenesis from the infused amino acids. However, the large increases in plasma insulin were not the result of the small increases in blood glucose that occurred during the infusions of the amino acid solutions. When greater or similar increases in blood glucose were produced by the intravenous administration of glucose or glucagon, the increases in plasma insulin were small. Administration of $30 \mathrm{~g}$ of amino acid mixtures and of certain individual amino acids produced larger increases in plasma insulin than did the infusion of $30 \mathrm{~g}$ of glucose.

The effects of the hyperinsulinemia that resulted from amino acid administration were manifested by decreases in blood glucose and plasma free fatty acids.

We conclude that 1 ). intravenous administration of mixtures of essential $l$-amino acids induces release of insulin; 2) the phenomenon of amino acidinduced release of insulin does not depend upon the presence of leucine in the infusion mixtures; 3) intravenous administration of individual essential amino acids induces release of insulin; however, there are large differences among these amino acids in their capacities to stimulate secretion of insulin; and 4) since it has been demonstrated that protein feeding induces increases in plasma insulin, amino acids can now be considered to be physiologic stimuli for the secretion of insulin.

\section{Acknowledgment}

We thank Dr. William J. Schull, Department of Human Genetiss, University of Michigan, who provided help with the statistical analysis of the data.

\section{References}

1. Floyd, J. C., Jr., S. S. Fajans, R. F. Knopf, J. Rull, and J. W. Conn. Postprandial aminoacidemia and insulin secretion, a physiologic relationship (abstract). J. Lab. clin. Med. 1964, 64, 858.

2. Floyd, J. C., Jr., S. S. Fajans, R. F. Knopf, J. Rull, and J. W. Conn. Stimulation of insulin secretion by amino acids (abstract). Clin. Res. 1965, 13, 322.
3. Floyd, J. C., Jr., S. S. Fajans, J. W. Conn, R. F. Knopf, and J. Rull. Insulin secretion in response to protein ingestion. J. clin. Invest. 1966, 45, 1479.

4. Fajans, S. S., R. F. Knopf, J. C. Floyd, Jr., L. Power, and J. W. Conn. The experimental induction in man of sensitivity to leucine hypoglycemia. J. clin. Invest. 1963, 42, 216.

5. Floyd, J. C., Jr., S. S. Fajans, R. F. Knopf, and $\mathrm{J}$. W. Conn. Evidence that insulin release is the mechanism for experimentally induced leucine hypoglycemia in man. J. clin. Invest. 1963, 42, 1714.

6. Fajans, S. S., J. C. Floyd, Jr., R. F. Knopf, and J. W. Conn. Secretion of insulin induced by leucine in healthy subjects in Ciba Foundation Colloquia on Endocrinology. Aetiology of Diabetes Mellitus and Its Complications, M. P. Cameron and M. O'Connor, Eds. London, Churchill, 1964, vol. 15, pp. 99-106.

7. Fruton, J. S., and S. Simmonds. General Biochemistry, 2nd ed. New York, John Wiley, 1958, pp. 673, 725.

8. Nelson, N. A photometric adaptation of the Somogyi method for the determination of glucose. J. biol. Chem. 1944, 153, 375.

9. Yalow, R. S., and S. A. Berson. Immunoassay of endogenous plasma insulin in man. J. clin. Invest. 1960, 39, 1157.

10. Fajans, S. S., J. C. Floyd, Jr., R. F. Knopf, and J. W. Conn. A comparison of leucine- and acetoacetate-induced hypoglycemia in man. J. clin. Invest. 1964, 43, 2003.

11. Frame, E. G., J. A. Russell, and A. E. Wilhelmi. The colorimetric estimation of amino nitrogen in blood. J. biol. Chem. 1943, 149, 255.

12. Dole, V. P. A relation between non-esterified fatty acids in plasma and the metabolism of glucose. J. clin. Invest. 1956, 35, 150.

13. Coon, W. W. Personal communication.

14. Yalow, R. S., S. M. Glick, J. Roth, and S. A. Berson. Plasma insulin and growth hormone levels in obesity and diabetes. Ann. N. Y. Acad. Sci. 1965, 131, 357.

15. Yalow, R. S., and S. A. Berson. Dynamics of insulin secretion in hypoglycemia. Diabetes 1965, 14, 341.

16. Floyd, J. C., Jr., S. S. Fajans, C. Thiffault, E. M. Guntsche, and J. W. Conn. Unpublished observations.

17. Floyd, J. C., Jr., S. S. Fajans, J. Rull, R. F. Knopf, M. M. Kirsh, and J. W. Conn. Direct evidence that leucine induces release of pancreatic insulin (abstract). Diabetes 1965, 14, 439.

18. Knopf, R. F., S. S. Fajans, J. C. Floyd, Jr., and J. W. Conn. Comparison of experimentally induced and naturally occurring sensitivity to leucine hypoglycemia. J. clin. Endocr. 1963, 23, 579.

19. Samols, E., G. Marri, and V. Marks. Promotion of insulin secretion by glucagon. Lancet 1965, 2, 415. 
20. Crockford, P. M., D. Porte, Jr., F. C. Wood, Jr., and R. H. Williams. Effect of glucagon on serum insulin, plasma glucose and free fatty acids in man. Metabolism 1966, 15, 114.

21. Cahill, G. F., Jr. Personal communication.

22. Mellinkoff, S. M., H. N. Shibata, M. Frankland, and M. Greipel. The effect of pancreatectomy upon blood sugar and serum amino acid concentration following the administration of amino acids. J. Lab. clin. Med. 1956, 48, 529.

23. Knopf, R. F., J. W. Conn, J. C. Floyd, Jr., S. S. Fajans, J. A. Rull, E. M. Guntsche, and C. A.
Thiffault. The normal endocrine resporise to ingestion of protein and to infusions of amino acids. Sequential secretion of insulin and growth hormone. Trans. Ass. Amer. Phycns 1966, 79, in press.

24. Knopf, R. F., J. W. Conn, S. S. Fajans, J. C. Floyd, Jr., E. M. Guntsche, and J. A. Rull. Plasma growth hormone response to intravenous administration of amino acids. J. clin. Endocr. 1965, 25, 1140 .

25. Merimee, T. F., D. A. Lillicrap, and D. Rabinowitz. Effect of arginine on serum-levels of human growth hormone. Lancet 1965, 2, 668. 